\title{
Mangrove system dynamics in Southeast Asia: linking livelihoods and ecosystem services in Vietnam
}

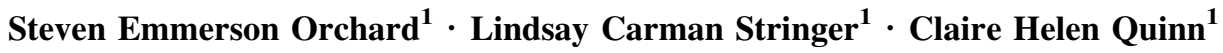

Received: 29 October 2013/Accepted: 18 April 2015/Published online: 12 May 2015

(C) The Author(s) 2015. This article is published with open access at Springerlink.com

\begin{abstract}
Across Southeast Asia, human activity has caused rapid mangrove system degradation and loss. In Vietnam, a country undergoing economic transition, mangrove systems are vital to the livelihoods of coastal rural communities. This paper studies three mangrove systemdependent communities on Vietnam's northern coast. Guided by the sustainable livelihood framework, the paper adopts a mixed methods approach. It presents current uses of mangrove system goods and the factors shaping past livelihood responses to mangrove system change, using livelihood trajectory analysis. Findings demonstrate that communities depend on mangrove systems to different degrees for income, subsistence and to respond to change. However, the rapid development of aquaculture is associated with a significantly reduced and degraded mangrove system commons necessary to support the livelihoods of low-income households. Three distinct livelihood trajectories are identified: consolidator groups able to use their access to a wide range of resources, locked into resilient trajectories; accumulator groups able to use their access to
\end{abstract}

Editor: Wolfgang Cramer.

Electronic supplementary material The online version of this article (doi:10.1007/s10113-015-0802-5) contains supplementary material, which is available to authorized users.

Steven Emmerson Orchard

eeseo@leeds.ac.uk

Lindsay Carman Stringer

1.stringer@leeds.ac.uk

Claire Helen Quinn

c.h.quinn@leeds.ac.uk

1 Sustainability Research Institute, School of Earth and

Environment, University of Leeds, Leeds,

West Yorkshire LS2 9JT, UK limited resources to move from vulnerable to more resilient trajectories; and marginalised groups facing increasingly reduced access to resources locked into vulnerable trajectories. Vietnam faces challenges in reconciling a more market-orientated economy with the maintenance of mangrove system functions and processes that shape the vulnerability and resilience of livelihood trajectories. Policies and projects promoting the sustainable management of mangrove systems should acknowledge the substantial contribution and multiple uses of mangrove systems in livelihoods, particularly of the poor, and the impact of aquaculture on income equality and livelihood diversity that shapes household resilience and vulnerability.

Keywords Resilience - Vulnerability - Coastal zone management $\cdot$ Sustainable development $\cdot$ Natural resource management

\section{Introduction}

Southeast Asian mangrove systems are the most biodiverse in the world (Friess et al. 2012), and the goods and services they provide are important components of coastal livelihoods (Van Hue and Scott 2008). Nevertheless, rapid development throughout the region has significantly altered mangrove systems, causing widespread degradation and loss (Gopal 2013). In Vietnam, political and economic reform has facilitated rapid development and vast areas of mangroves have been converted to large-scale, intensive aquaculture (Tri et al. 1998). This trend is particularly alarming in rural areas, where many livelihoods depend on mangrove system commons for collection of fish, crustaceans and other sea life for food and income. Additional 
goods and services from mangrove systems include: wood for fuel and energy; protection of shorelines from erosion, flooding and storm damage; and to filter pollutants and maintain water quality (Spalding et al. 2010).

Mangrove system degradation and loss occurs through deliberate and inadvertent actions resulting from undervaluation of ecosystem functions and processes (Vilardy et al. 2011). Political, socio-economic and environmental disturbances can negatively impact the structure, function and flow of the goods and services ecosystems provide to society, causing significant impacts on human welfare (MEA 2005). Households in natural resource-dependent communities respond to disturbance through their livelihoods. Livelihoods are shaped by past decisions and access to natural resource commons, steering households along particular livelihood trajectories (Bagchi et al. 1998). Despite growing interest in understanding how human activities are altering ecosystem goods and services, little research has studied how the factors shaping past decisions in response to ecosystem change have shaped the livelihood trajectories of households in mangrove resourcedependent communities (MRDC). To address this gap, this paper examines the livelihoods of three MRDC in northern Vietnam. It provides valuable insights into mangrove system change and the interdependencies of human activity and mangrove goods and services, through empirical analysis in an understudied development context of a rapidly growing transition economy.

Vietnam's transition from a highly centralised planned economy to a socialist-orientated market economy was initiated in 1986 (Đổi Mới). Reforms included: devolution of land management from centralised collectives to households; decentralisation of land allocation decisionmaking to local government; and market liberalisation, while the Communist Party has retained political control. Although transition has fostered significant economic gains, a set of intractable social and environmental issues remain, such as growing inequality and natural resource degradation (Adger 2000). Studying the implications of this transition for the livelihoods of MRDC can extend our understanding of the interdependencies between human activity and mangrove goods and services.

This paper presents the current use of mangrove goods and services. It also identifies the factors influencing past livelihood decisions and the vulnerability and resilience of livelihood trajectories within MRDC. The objectives are to: (1) identify the key aspects impacting the dynamics of each mangrove system; (2) establish the range of mangrove system-related livelihood activities households currently engage in; (3) identify household characteristics related to differing levels of mangrove system dependency and use; and (4) establish which aspects of change have influenced livelihood trajectories of households with different levels of mangrove system dependency and use. Quantitative and qualitative methods are integrated within a case study approach. Integrating the sustainable livelihood framework (SLF) with ecosystem service and livelihood trajectory approaches permits understanding of the links between mangrove system change and livelihood responses. The ecosystem service approach allows categorisation of the goods and services that households receive from mangrove systems, allowing comparison of current livelihood strategies and activities across the studied MRDC. Livelihood trajectory analysis allows the charting of mangrove system change over time and exploration of how processes of change have shaped the livelihoods of households with different levels of mangrove system dependency.

The research enhances knowledge on livelihoods and natural resource management and provides insights for future mangrove system planning, through identification of key livelihood vulnerabilities and their drivers. We find that in the context of rapid social and environmental change across Southeast Asia, intensive large-scale commercial aquaculture is: reducing the resilience of livelihoods through losses in buffering capacity and livelihood diversity in response to disturbance; and increasing vulnerability through reduced access to mangrove system commons and increasing livelihood sensitivity by removing a crucial source of livelihood response. Households with greater dependence on a significantly declining and degraded mangrove commons find their livelihood options reduced, locking them into livelihood trajectories that can leave them more vulnerable.

The next sections outline central concepts related to livelihoods, ecosystem services and the research process. Narratives of mangrove system dynamics within each context are provided, exploring the political, socio-economic and environmental aspects contributing to contemporary livelihood strategies. Quantitative analysis then offers insights into the contribution of mangrove systems to households' current livelihood portfolios. Livelihood trajectories of individual households are then examined, providing an essential temporal dimension. Lessons from such insights are then discussed.

\section{Central concepts}

A livelihood comprises the capabilities, assets (including both material and social resources) and activities required to make a living (Chambers and Conway 1992). Assets are the tangible and intangible resources, categorised by Scoones (1998) as natural, social, financial, physical and human capitals. The mix of assets and activities a household employs denotes the "livelihood strategy" (Scoones 1998) and also encapsulates cultural and social elements (Ellis 2000). Livelihoods are shaped by the changing 
natural environment and form within complex social, economic and political contexts; the "shocks", "trends" and "seasonality" of which combine to determine the livelihood vulnerability context (Chambers and Conway 1992; Scoones 1998). Throughout this paper, shocks, trends and seasonality are collectively referred to as disturbance.

A livelihood is considered sustainable when "it can cope with and recover from stresses and shocks and maintain or enhance its capabilities and assets both now and in the future, while not undermining the natural resource base" (Scoones 1998: p 2). Consideration of sustainability within a livelihood approach resonates with concepts of resilience theory (Marschke and Berkes 2006). Resilience refers to "the capacity of a system to experience shocks while retaining essentially the same function, structure, feedbacks and therefore identity" (Walker et al. 2004: p 2). Nevertheless, the application of concepts relating to ecological resilience in relation to social systems has been questioned because of their inattention to power (Duit et al. 2010), while a resilient system does not indicate whether or not it is in a socially preferred ecological or socio-economic state, or who decides this (Armitage et al. 2012). Both sustainable livelihood and resilience approaches have lacked integration with both livelihood and natural resource system history (Vilardy et al. 2011).

The millennium ecosystem assessment (MEA) broadly defines ecosystem services as the benefits people obtain from natural ecosystems (MEA 2005). The MEA provides a framework that considers feedbacks at multiple scales among direct and indirect aspects of change, ecosystem services and human well-being, organising ecosystem services under provisioning, regulating, cultural and supporting service categories. The MEA framework nevertheless fails to consider the full ensemble of process and feedbacks required to fully understand complex and dynamic human-ecosystem relations (Carpenter et al. 2009). Ecosystem service approaches tend to focus on current ecosystem benefits and economic value while neglecting political aspects and lack consideration of time (Norgaard 2010).

With the aforementioned limitations in mind, we combine ecosystem service and livelihood approaches to explore livelihood trajectories, i.e. the directions that livelihoods follow over time (Sallu et al. 2010). Such an approach allows exploration of the life histories of individual households and their strategic behaviour, and the changing use of mangrove system goods and services in their livelihoods. It enables close examination of dynamic human-environment links between mangrove systems and dependent communities and fosters understanding of the political, socio-economic and environmental aspects underpinning the provision of mangrove system goods and services and the ways people use and manage these services over time (Vilardy et al. 2011).
Fig. 1 Study site locations and coordinates. Source Wikipedia (2014)

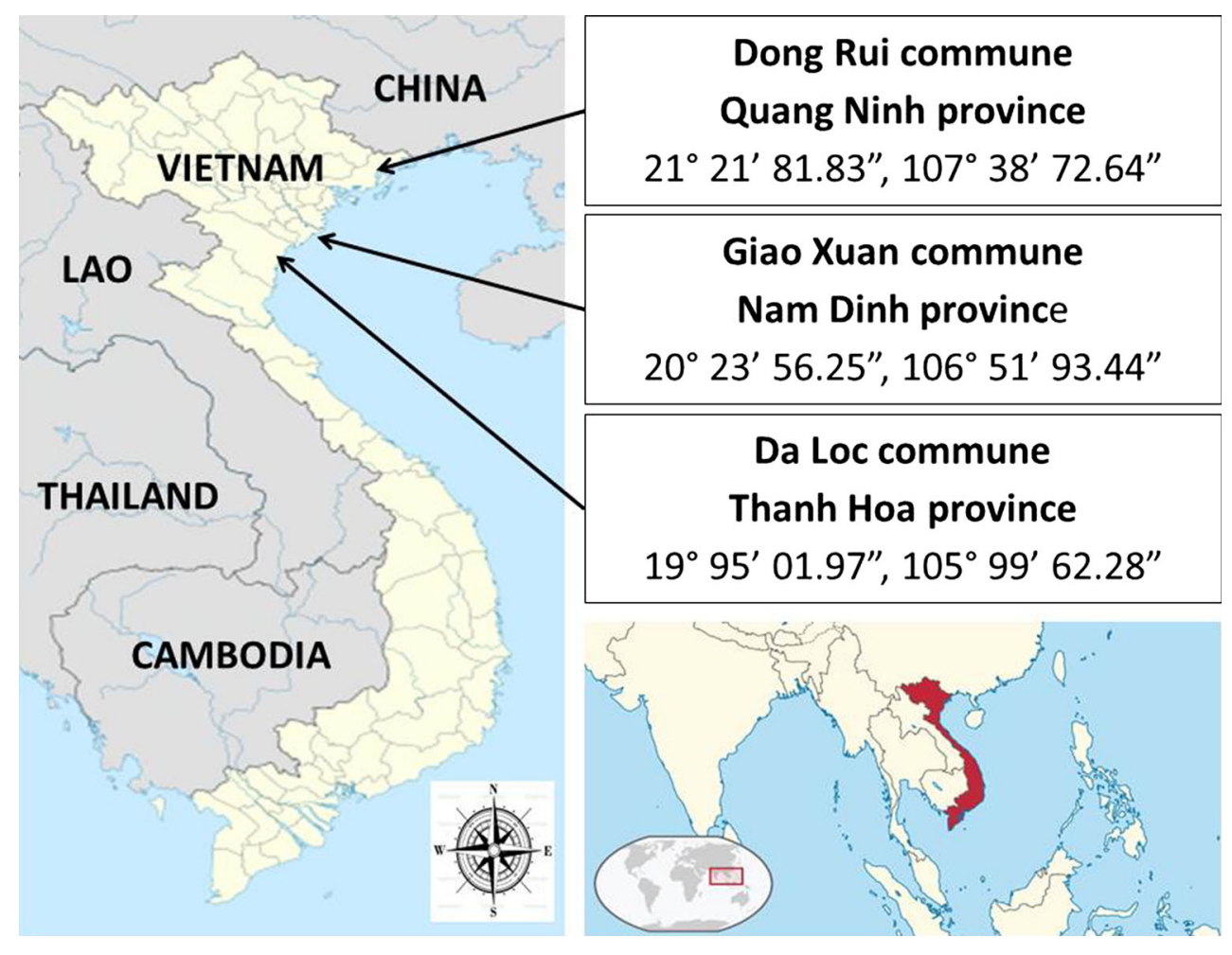




\section{Materials and methods}

Data were collected using mixed methods during February-August 2012, in mangrove systems of three coastal communities in northern Vietnam: Giao Xuan (Nam Dinh Province); Da Loc (Thanh Hoa Province); and Dong Rui (Quang Ninh Province) (Fig. 1). A community is considered a subset of a commune and defined as a socioeconomic impact area of a given mangrove system (Glaser 2003). Communities represented mangrove systems that are distinct, geographically separate and with different histories. The mangrove systems comprised the interdependent components of trees and intertidal mudflat areas from which communities acquired provisioning goods. In all three communities, mangrove system provisioning goods (MSPG) refer to the wild fish, clam, shrimp, crab and other shoreline animals collected from mangrove system commons.

Transect walks with local authority and NGO representatives through mangrove system corridors were conducted in each community during scoping studies at the beginning of field work. These aided familiarisation with local context, history and issues relating to each mangrove system and enabled more targeted questioning during the main period of data collection. Participant observation of households collecting MSPG and informal conversations with wider community members provided further useful initial information.

Household surveys $(n=248)$ were conducted with household heads to identify current livelihood strategies and mangrove system use patterns (Giao Xuan, $n=79$; Da Loc, $n=70$; Dong Rui, $n=99$ ). In this study, household heads are those individuals contributing the largest amount to household income. Semi-structured interviews provided in-depth historical and current perspectives on livelihood strategies and trajectories ( $n=10$ in each community; total $n=30$ ). Semi-structured interviews elucidated: (a) how households use mangrove systems, (b) how changes in the mangrove system (degradation, storm damage, etc.) affect livelihood decisions, and (c) how aspects identified in (a) and (b) interact with broader political, socio-economic and environmental aspects to determine outcomes and subsequent livelihood impacts.

To achieve objectives 1-3, surveys requested general household information (age, gender, education, etc.) and data on all subsistence and income generating activities. Respondents were selected with the help of local partners and key informants to identify an initial set of households that used the mangrove system for their livelihoods. These households then identified further respondents in a snowball sampling approach (cf. Luttrell 2006). Sampling continued in a respondent-driven way (Heckathorn 1997) until saturation had been reached (i.e. the same names reoccurred in the lists of names provided by respondents). As the composition of the total sample was wholly independent of the initial respondents, it yielded unbiased samples (Heckathorn 1997). This avoided spending time talking to respondents who were not mangrove-dependent. To enable assessment of the relative importance of mangrove resources to household livelihoods, specific information was collected on seasonality, effort, yield and income from mangrove goods. To achieve objective 4 , livelihood trajectory data were collected through semi-structured interviews, which covered key events that altered mangrove systems and the subsequent changes in livelihood activities (cf. Sallu et al. 2010). Semi-structured interview participants were selected from survey respondents, maintaining a balance between broad categories of household based on wealth, gender, age and ethnicity (Luttrell 2006). The time covered by the semi-structured interviews was limited to 1975-2012. This covers the period from Vietnam's reunification to the present, encapsulating the collectivised farming era and subsequent political and economic changes: significant events in setting the boundaries of the livelihood context.

Data analysis was iterative and initially involved descriptive analysis to $\log$ trends and patterns in preliminary data collected during scoping studies. More detailed analysis was conducted as quantitative and qualitative data accumulated. Quantitative data analysis first explored frequencies of MSPG use in livelihoods using SPSS (IBM SPSS 19). Data were then analysed using Kruskal-Wallis and Mann-Whitney tests (cf. Cox et al. 2010), with independent livelihood variables categorised using cluster analysis and tested against the dependent variable of percentage of household income derived from MSPG (Brouwer et al. 2007). Qualitative data were coded under emerging themes (Kaplowitz 2001). During livelihood trajectory analysis, tendencies towards resilience or vulnerability were determined by an increase or decrease in access to financial, human, physical, social or natural capitals. This facilitated identification of aspects of change that had played a major role in shaping livelihood strategies. Contradictions and similarities were exposed through repetitive triangulation of findings. Continual iterative reflections were carried out jointly with research participants as further data and results emerged, to determine how and why any conflicts in information may have occurred. This was done via continual dialogue through follow-up interviews and focus groups discussions to validate findings. This resulted in a cyclical process cumulating in inductive interpretation and explanation of results as livelihood system data were positioned within the dynamic socioeconomic and political context. 


\section{Results}

\section{Key aspects of change in the mangrove system}

Results in this section are from analysis of transect walk data, semi-structured interviews and focus groups. Mangrove system change is shaped by a complex set of political, socio-economic and environmental aspects identified by research participants (Table 1). Large-scale and intensive commercial aquaculture, privatisation of mangrove system tenure rights and the role of local authorities were important in all three communities, along with market liberalisation, participation and pollution in Giao Xuan, Da Loc and Dong Rui, respectively. In Giao Xuan and Da Loc, aquaculture comprises large-scale and intensive commercial clam cultivation along the shoreline, while in Dong Rui it refers to large-scale, intensive commercial shrimp cultivation. The unique interactions of political, socio-economic and environmental aspects have defined the contours of the local livelihood context, creating both opportunities and threats to livelihoods over time.

In all three communities, MSPG played a key role in livelihoods during collectivised farming (1975-1986), when agricultural land was allocated to households and mangrove systems were considered common property. Community rules and traditions determined what people could and could not do. MSPG were crucial for livelihoods,

Table 1 Factors of mangrove change

\begin{tabular}{llll}
\hline Factors & Giao Xuan (\%) & Da Loc (\%) & Dong Rui (\%) \\
\hline Aquaculture & 73 & 71 & 87 \\
Property rights & 47 & 29 & 67 \\
Local authorities & 53 & 29 & 60 \\
Pollution & 40 & 18 & 54 \\
Markets & 54 & 29 & 14 \\
Participation & - & 41 & 40 \\
Household use & 40 & 6 & 40 \\
Regulation & 30 & 18 & 30 \\
Awareness/ & 33 & 6 & 27 \\
$\quad$ education & & & \\
Ecological processes & 20 & 18 & - \\
Population & 20 & 23 & - \\
Severe weather & 20 & 6 & 7 \\
Infrastructure & 20 & 6 & - \\
Finance & 20 & - & - \\
National policy & 13 & - & - \\
Knowledge/skills & 13 & - & - \\
War & 7 & - & - \\
\hline
\end{tabular}

The percentage of interview respondents identifying specific factors in respective communities is provided, while (-) indicates that a factor was not identified (sample sizes: Giao Xuan, $n=15$; Da Loc, $n=17$; Dong Rui, $n=15$ ) but with no markets for them, there was little incentive to overexploit. In Dong Rui, following the Sino-Vietnamese War (1979), extensive sections of mangrove system land formerly settled by ethnic Chinese groups (approximately $100 \mathrm{~km}$ from the Chinese border) were resettled by ethnic "Kinh" Vietnamese from nearby Hai Phong City. Đổi Mới political and economic reforms (1986) fostered lucrative domestic and international markets for MSPG, while changes to the Land Law (1993) devolved land management from the central state to individual households, privatising tenure rights, and decentralised land allocation authority to local government. Subsequently, regulatory frameworks have struggled to keep pace with changing social, political, economic and environmental conditions. In Dong Rui, subsequent to economic reforms, huge swathes of mangrove system land were sold to shrimp aquaculture investors from Hai Phong City and surrounding coastal provinces, who had connections to the newly established local authorities. This was done without community consultation, often illegally, by signing land-use contracts using the names of friends, family and community members to circumvent restrictions on the amount of land any one person could own.

During the early 1990s, aquaculture was established on the intertidal mudflat areas in Giao Xuan, with some households benefiting from strong trade links with China and access to lucrative clam markets. Aquaculture took longer to establish in Da Loc due to a lack of trade links and relatively little knowledge of aquaculture farming techniques. However, in the late 2000s, locals observed the financial benefits gained through clam farming in neighbouring provinces and aquaculture increased. Growing numbers of people in Giao Xuan and Da Loc claimed land in mangrove areas to establish clam farms, and this caused conflicts within communities. Local authorities intervened by dividing mangrove systems into plots which were auctioned to local households. The authorities benefitted financially through auction processes and subsequent land taxes, while wealthy households and those closely connected to local authorities gained disproportionately.

In all three communities, in addition to poorer households having a vastly reduced area from which to collect MSPG due to the privatisation of mangrove system tenure rights, the quantity and quality of MSPG reduced due to the environmental impacts of increased aquaculture. In Giao Xuan and Da Loc, there was concern about disease outbreaks (i.e. infections caused by viral, bacterial and parasitic agents) from aquaculture. Fears were also raised regarding the combined ecological impact of importing vast amounts of alien clam species and associated sand varieties to prepare land for intensive cultivation. Alien species can outcompete and reduce abundance of naturally occurring local species, while imported sand varieties alter 
the local environmental conditions that local species require to thrive. In Dong Rui, the community's negative experience of mangrove system conversion to aquaculture raised concerns about the subsequent alteration of the hydrological flows that regulate and support the ecosystem. These, along with pollution from the waste discharge of the growing aquaculture industry, were households' main concerns. Dong Rui experienced the complete collapse of the aquaculture industry in the early 1990s (which was owned by external investors) due to mismanagement by local authorities. Such collapse caused severe and widespread degradation in surrounding mangrove system areas.

\section{Current livelihood strategies and activities at the aggregate community level}

Results in this section are from the analysis of quantitative data from household surveys. In the context of the above changes, and considering divergent historical perspectives, each community exhibits a distinct set of livelihood strategies and corresponding activities today. High levels of aquaculture activity in Giao Xuan are associated with higher incomes, represented by significantly higher average annual income per capita than in Da Loc and Dong Rui (supplementary material Table S1). In Giao Xuan, although aquaculture has significantly contributed to higher incomes, especially for aquaculture farm owners, inequality is reflected in the range of average total household incomes.

Despite comparable average total household incomes between Da Loc and Dong Rui, the almost three times greater income range in $\mathrm{Da}$ Loc suggests that the growing aquaculture industry is associated with higher income inequality. Households with the highest incomes are clam farm owners and employees. Although aquaculture has increased the total number of livelihood options available to households in Giao Xuan and Da Loc, the proportion of total livelihood activities each household engages in is higher in Dong Rui. This indicates that households in communities with aquaculture have less diverse livelihoods.

In all three communities, mangrove-based livelihood activities contribute a significant proportion to total income (Fig. 2). Conversely, even though $100 \%$ of households in each community are engaged in on-farm activities, these tend to be for household consumption and contribute only a small proportion to total income. Although a small number of households are engaged in off-farm livelihood activities in all communities, income from these activities contribute a larger proportion to total income compared to on-farm activities. Households with more income from on-farm and off-farm activities tend to have lower amounts of income from mangrove systems.

Specific livelihood activities relating to mangrove systems in all three communities include the ownership of aquaculture farms, employment on aquaculture farms and collection of wild fish, clam, shrimp and crab from the mangroves for household consumption and/or sale (Fig. 3). A number of households are engaged in more than one of these activities. In Giao Xuan, while only $37 \%$ of households own aquaculture farms it contributes $85 \%$ of total income for that community. Although a higher percentage of households are engaged in aquaculture employment (74 \%), the proportion of income gained through this

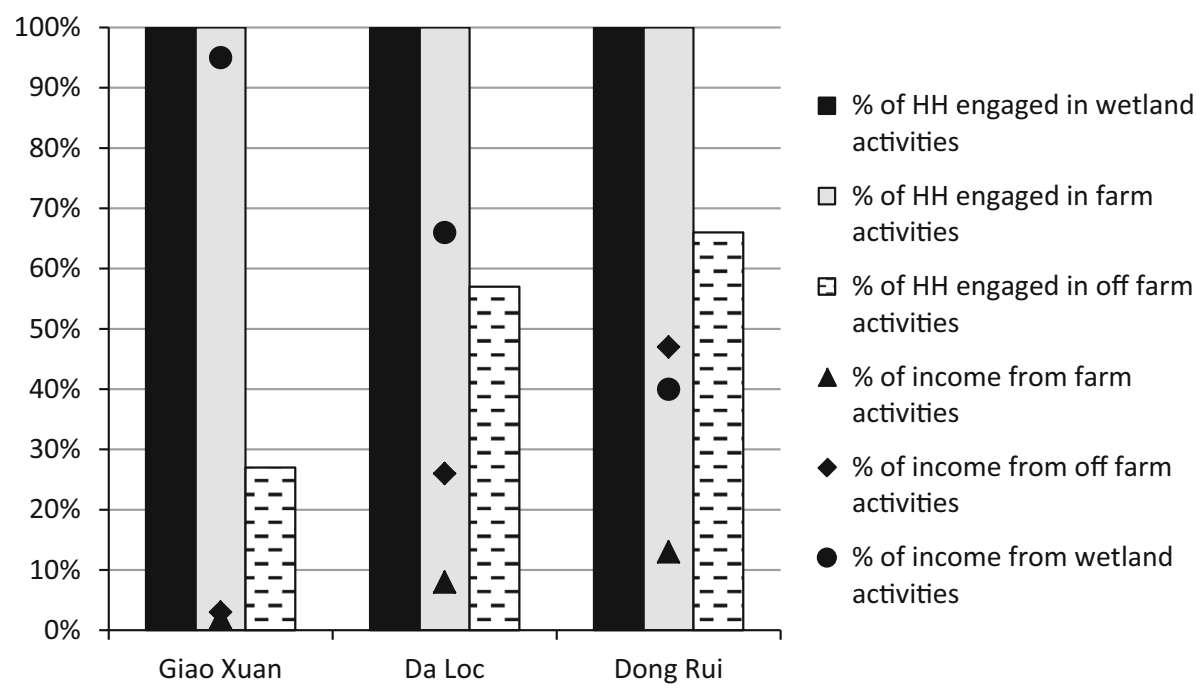

Fig. 2 Community livelihood categories (wetland, on-farm and offfarm) and percentage contribution to total income. Wetland activities comprise aquaculture farming, aquaculture employment and wild foraging. On-farm activities comprise crop cultivation (sweet potato,

peanut, maize, bean, chilli, sugar cane and fruit) and livestock tending (buffalo, pig, chicken and duck). Off-farm activities include fishing, industry, service, migration. Sample sizes: Giao Xuan, $n=79$; Da Loc, $n=70$; Dong Rui, $n=99$ 
Fig. 3 Breakdown of wetland livelihood activities (aquaculture farming, aquaculture employment and wild foraging) and per cent of total income. Sample sizes: Giao Xuan, $n=79$; Da Loc, $n=70$; Dong Rui, $n=99$. $N B$. $A C$ aquaculture

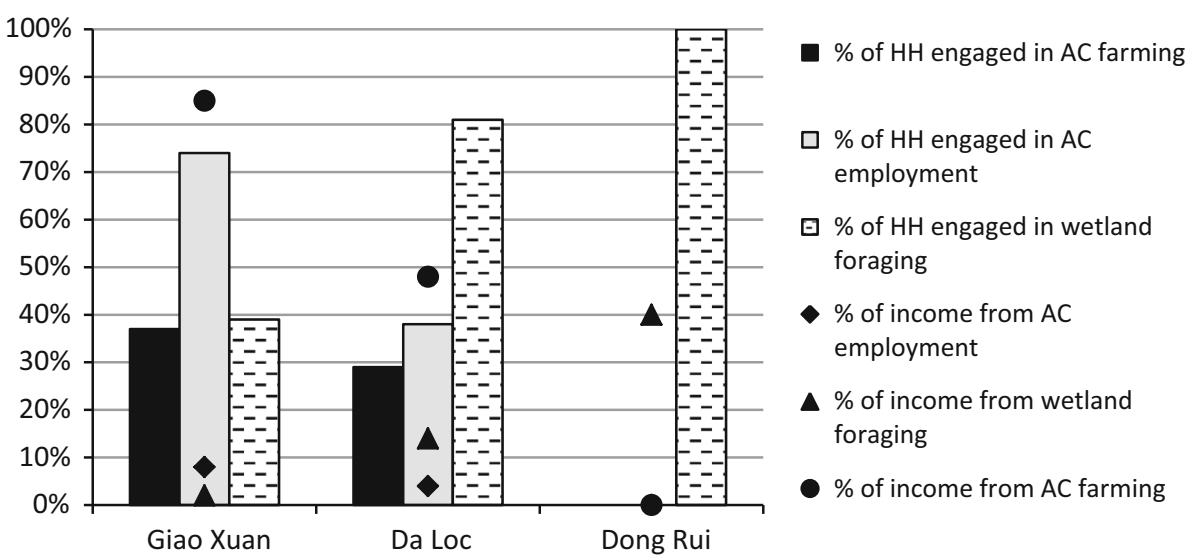

activity is low (8\%). Even though $39 \%$ of households are engaged in MSPG collection, it constitutes only $2 \%$ of total income. The unequal distribution of income in Giao Xuan is further apparent because of the $95 \%$ of total income generated through mangrove system activities, and only $6 \%$ comes from aquaculture employment and $1 \%$ from MSPG. The remaining $88 \%$ is derived from the ownership of mangrove system tenure rights that enable income through profits made on aquaculture farms.

In Da Loc, where aquaculture farming is in its infancy, a notable portion of households in the community are engaged in it $(29 \%)$, and it represents a large portion of aggregate community income (48\%). Over twice as many households in the community are engaged in MSPG collection $(81 \%)$ compared to aquaculture employment (38\%), MSPG collection represents over three times the proportion of aggregate community income (14\%) compared to aquaculture employment (4\%). A larger number of households are engaged in non-wetland-related livelihood activities than those observed in Giao Xuan (Fig. 2). In Dong Rui, which experienced aquaculture industry collapse, no households engage in aquaculture farming or employment, and $100 \%$ engage in collecting MSPG, representing $40 \%$ of total income, with the remaining $60 \%$ coming from non-wetland-related activities.

These results indicate that when the commercial aquaculture industry is strong: aggregate community income tends to be unequally distributed and concentrated among aquaculture farmers; average household livelihood diversification is lower; and marginalised households remain dependent on collecting MSPG as a livelihood activity.

\section{Characteristics of households most dependent on MSPG and their use}

Results in this section come from the analysis of quantitative data from household surveys and qualitative data from semi-structured interviews and focus groups. In each community, households most dependent on MSPG for their livelihoods were characterised (Tables 2, 3, 4; Table S2 shows the breakdown of variable groups). Female-headed households were more dependent on MSPG than maleheaded households in all three communities. In Giao Xuan and Da Loc, where aquaculture prevails, households with less secure mangrove system tenure rights were more dependent on MSPG than those with more secure tenure rights. Where commercial aquaculture is in its infancy or has collapsed (Da Loc and Dong Rui, respectively), households with low education levels were more dependent on MSPG than those with higher education levels. In Giao Xuan, there was more dependence on MSPG among households with high livelihood diversity, while in Dong Rui, higher MSPG dependency was found among households with low livelihood diversity. As low-income households were found to be more mangrove system-dependent in both these communities, this indicates that lowincome households in Giao Xuan are using mangroves to diversify their livelihoods, while low-income households in Dong Rui are not. This could be because Dong Rui does not have a commercial aquaculture industry, hence lacking options for diversification.

All three communities benefit greatly from mangrove ecosystem services (Table S3). Provisioning and regulating services were the most identified services among all communities, representing more direct benefits. However, perceptions differed between communities. In Giao Xuan, provisioning services were identified more frequently by the highest number of households, with regulating services largely corresponding to storm protection benefits. In Da Loc, regulating services were identified more frequently and by more households. This could be due to experiences of extensive storm damage and saline intrusion from typhoon Damrey in 2005, with resulting damage to arable farm land still fresh in respondents' memories. In Dong Rui, a higher percentage of statements were made regarding regulating services compared with the other communities, although several households identified 
Table 2 Characteristics of households in Giao Xuan most dependent on MSPG for income

Table 3 Characteristics of households in Da Loc most dependent on MSPG for their income

Table 4 Characteristics of households in Dong Rui most dependent on MSPG for their income

\begin{tabular}{llllll}
\hline & \multicolumn{2}{l}{ Giao Xuan } & & \\
\cline { 2 - 6 } & Test statistic & Degrees of freedom & Sig. & $z$ score & Post hoc $r$ score \\
\hline Age & $10.961 \Omega$ & 4 & $0.027^{* *}$ & -3.219 & 0.001 \\
Gender & $352 \beta$ & - & $0.006^{* * *}$ & -3.00 & 0.3 \\
Education & - & - & - & - & - \\
Years lived in commune & - & - & - & - & - \\
Household members & - & - & - & - & - \\
Livelihood diversity & $13.344 \Omega$ & 2 & $0.001^{* * * *}$ & -3.454 & 0.001 \\
Income & $5.935 \Omega$ & 2 & $0.05^{* *}$ & -2.426 & 0.015 \\
Land user rights & $15.416 \Omega$ & 2 & $0.000^{* * * *}$ & -3.603 & 0.000 \\
\hline
\end{tabular}

\begin{tabular}{llllll}
\hline & \multicolumn{2}{l}{ Da Loc } & & & \\
\cline { 2 - 6 } & Test statistic & Degrees of freedom & Sig. & $z$ score & Post hoc $r$ score \\
\hline Age & - & - & - & - & - \\
Gender & $442.5 \beta$ & - & $0.087^{*}$ & -1.710 & -0.2 \\
Education & $375 \beta$ & - & $0.026^{* *}$ & -2.221 & -0.3 \\
Years lived in commune & $5.489 \Omega$ & 2 & $0.064^{*}$ & -2.228 & 0.026 \\
Household members & - & - & - & - & - \\
Livelihood diversity & - & - & - & - & - \\
Income & - & - & - & - & - \\
Land user rights & $10.459 \Omega$ & 2 & $0.005^{* * *}$ & -3.122 & 0.002 \\
\hline
\end{tabular}

\begin{tabular}{llllll}
\hline & \multicolumn{2}{l}{ Dong Rui } & & & \\
\cline { 2 - 6 } & Test statistic & Degrees of freedom & Sig. & $z$ score & Post hoc $r$ score \\
\hline Age & - & - & - & - & - \\
Gender & $685 \beta$ & - & $0.005^{* * *}$ & -2.786 & 0.3 \\
Education & $18.642 \Omega$ & 4 & $0.001^{* * *}$ & -2.656 & 0.008 \\
Years lived in commune & $13.409 \Omega$ & 2 & $0.001^{* * *}$ & -3.430 & 0.001 \\
Household members & $7.698 \Omega$ & 2 & $0.021^{* *}$ & -2.101 & 0.036 \\
Livelihood diversity & $24.459 \Omega$ & 2 & $0.000^{* * *}$ & -2.656 & 0.008 \\
Income & $11.649 \Omega$ & 2 & $0.003^{* * *}$ & -3.475 & 0.001 \\
Land user rights & - & - & - & - & - \\
\hline
\end{tabular}

$* p=0.05-0.1 ; * * p=0.049-0.011 ; * * * p=0.01-0$

$\beta$ Mann-Whitney test, $\Omega$ Kruskal-Wallis test provisioning services. In Dong Rui, which has no protective community dike, respondents highlighted that moderately intense storms can have severe negative impacts on their crops, and mangroves are seen as crucial for storm protection. With soil quality already poor, saline intrusion resulting from storms is a large community concern. Supporting services were the next most identified service across all communities, particularly soil retention, nutrient cycling, oxygen production and habitat provision. Cultural services were consistently ranked lowest in importance across all three communities, although Dong Rui respondents identified aesthetic qualities and heightened sense of well-being as important ecosystem benefits.

Semi-structured interviews and focus groups revealed that households use diverse strategies to respond to disturbance, such as increased collection of MSPG for sale, drawing on savings, bank loans, social and kinship networks, and sale of assets and labour. Sale of MSPG was the most important safety net in the face of economic shocks because it demanded less reliance on other people: the extended family are commonly poor so cannot offer support, and no repayments are incurred. The MSPG differ in 
Table 5 Species, and estimated effort, weight and price of provisional services from mangroves

\begin{tabular}{lllll}
\hline Catch & Season (height) & Est. effort (hrs) & Est. weight $(\mathrm{kg})$ & Est. \$/kg \\
\hline Giao Xuan & & & & \\
Fish & All year (March-July) & $5-6$ & $5-10$ & $1-1.5$ \\
Crab & All year (March-July) & $5-6$ & $3-4$ & 1.5 \\
Clam & All year & $5-6$ & $2-10$ & $1-3.5$ \\
Shrimp & All year (March-July) & $5-6$ & $5-30$ & $3-5$ \\
Da Loc & & & & 5 \\
Fish & All year (February-April) & $5-6$ & 3 & 1 \\
Crab & All year (January-August) & $5-6$ & $4-5$ & 0.5 \\
Clam & All year (February-May) & $4-6$ & $6-7$ & $1-5$ \\
Dong Rui & & & 10 & $1-1.5$ \\
Fish & All year (April-June) & 8 & $6-8$ & $3-4$ \\
Crab & All year (March-August) & 3 & $5-7$ & $2-3$ \\
Clam & All year (May-September) & 6 & $2-4$ & $20-50$ \\
Worm & All year (September-February) & 8 & $0.5-1$ & 5 \\
Octopus & All year (June-August) & 6 & $4-6$ & $5-10.5$ \\
Shrimp & All year (September-December) & 6 & - & \\
Jellyfish & All year (February-March) & 6 & & \\
\hline
\end{tabular}

each community due to specific biophysical and geographic mangrove system characteristics (Table 5). Interviews indicated that in all three communities, households with higher dependence on MSPG rely on these goods to sell. Sale of MSPG helps them to cope with disturbances such as crop failures, seasonal fluctuations in the weather, unemployment, celebrations and the start of the new school year when money for schooling and equipment is needed. Semi-structured interviews and focus groups in Giao Xuan revealed that during August and September, when MSPG are at their least available, MSPG-dependent households find it most difficult to meet their subsistence needs. Interviews indicated that although prices offered for MSPG were relatively stable, this was due to wholesalers giving consistently low prices in order to maximise their profits.

\section{Livelihood trajectory analysis}

An in-depth analysis of the livelihood trajectories of illustrative households between 1975 and 2012 ascertained the influence of multiple and interacting key aspects of change that resulted in current livelihood strategies. The livelihood trajectories of five representative households illustrate the wider communities' experiences in using the mangrove system, encompassing all wealth groups (Table 6).

Three distinct types of livelihood trajectory exist across the three communities. The first group, (consolidators) start from a point of power and influence prior to political and economic reform and are currently successful aquaculture farm owners. These households are characterised by high incomes, a middle-aged male head, low livelihood diversity and more secure mangrove system tenure rights. They have typically been able to access MSPG through land grabbing and social influence and prosper through a combination of access to emerging external markets, capital, social networks and knowledge following market liberalisation. These households were typically influential during the collective farming era and have leveraged this position during market liberalisation to reinforce and increase access to land and resources. Their aquaculture ventures have been consolidated through acquisition of mangrove system tenure rights from struggling aquaculture farmers who lack the skills and knowledge to be successful. These households have also modified the environment in response to ecosystem feedbacks which undermine aquaculture productivity, e.g. by importing alien species of shrimp or clam, and related varieties of sand to accommodate them. Successful aquaculture farmers have also been able to form lobby groups to challenge the local authorities on decisions which impede their aquaculture activities and are able to profit by providing loans to poor households charged at interest. This trajectory of prosperity has been reinforced by some households by leveraging social influence and networks to their advantage.

The second group, (accumulators) were typically from poor backgrounds prior to political and economic reforms, lacking the influence, power and access to resources of the consolidators group. They have increased their incomes largely through aquaculture employment or collective ownership of small-scale aquaculture farms. Households are characterised by mid- to low-level incomes, male or female heads, mid-livelihood diversity to low livelihood 
Table 6 Livelihood trajectories of households most reflective of the impact of social-ecological dynamics

Case study household

Case 1-Male, age 54, Giao Xuan

Before economic reform, there was no market for mangrove system goods, so he and others in the community foraged MSPG for household consumption. Following economic reforms in 1986, he was employed on a trading boat, which took him to China where he first became aware of the lucrative clam market. He invited a specialist from China to Giao Xuan to teach him clam aquaculture techniques to produce clams for export to China. Subsequent to the success of this, other locals were attracted to mangrove system land to cultivate clams as a commodity and began to assert claims over sections of the land. By 1991, overexploitation resulted in the complete collapse of the native clam population. In 1992, however, he was able to draw on accumulated capital and trading links with neighbouring provinces to import clam seed varieties to cultivate before selling on to China. This was highly successful and the market peaked in 1995. By 1997, however, the imported clams began to die due to incompatibility with local environmental conditions. Many clam fields were abandoned and became available for him to buy as a result. Undeterred, he decided to search further afield, to provinces in the south of Vietnam, to find clam species more suited to local conditions. In 1999, he combined the import of new clam species with new sand varieties to accommodate them. Although there was initial scepticism due to past failures, the enterprise was a success and markets developed both domestically and internationally. Furthermore, due to the stabilising effect on the environment from mangrove restoration efforts, he no longer needs to import clam seeds from the south. Clam farming is now the major industry in Giao Xuan, which is now one of the biggest producers in Vietnam. Although the industry is more stable now, he still has to make periodic alterations to his fields in order to maintain productivity. He is aware that importing clam and sand varieties is unsustainable and is trying to reintroduce native species

Case 2-Female, age 51, Giao Xuan

She has lived in Giao Xuan all her life, where she lives with her 21-year-old son. When she was young, her family was poor and life was difficult; often there would not be enough food to eat, and they would have to rely more heavily on foraged MSPG for subsistence. There was no state support at the time, so when her family found themselves in hardship they would have to ask for loans from rich households which they had to pay back with interest. Following the birth of her son, she lost her husband and had to rely on her husband's family to support her and her new born baby. When the clam aquaculture sector began, she could not get access to any land for farming because she was not strong enough to claim land, and she was not rich enough to buy any. Even if she had the money, because she is a woman she cannot own land. When the clam aquaculture sector expanded, she was young and healthy and able to find employment through family contacts. She established a reputation for being a good worker and was respected by her work colleagues, and so aquaculture owners began to ask her to manage work teams on their behalf. She has been able to develop such a wide network of contacts within the industry that she can even find employment in neighbouring districts. Her son is now old enough to contribute to household income, and he is also employed on aquaculture farms. However, clam aquaculture does not provide stable employment, particularly during the winter, so she still has to forage MSPG to supplement her income. In recent years, the rains have been less predictable and this has affected her rice crop, so she has to depend heavily on foraging MSPG when this happens. She cannot make as much money from this as she did in the past, as there is less space to forage MSPG and fewer animals available to harvest, even though there are lots more animals in the aquaculture fields. She believes that clam aquaculture is eradicating the natural species and is worried that eventually there will be no MSPG to forage

\section{Case 3-Female, age 46, Giao Xuan}

When she was young she would forage MSPG with her family for household consumption. When the mangrove system area her family had traditionally collected from was divided up and turned into clam aquaculture fields, her husband joined a collective that pooled all their savings together to buy a field. Combined with the income she received from labouring on clam aquaculture fields, they earned enough income for food and to send their son to school. When her husband became terminally ill, he could no longer work, and she had to work fewer hours to tend to him. They received no state support, and with hospital bills mounting, they were forced to sell everything they owned and move into a smaller house next to the dike. The land near the dike is low quality and not suitable for growing crops, and household assets, such as livestock, are often stolen by groups of thieves that target vulnerable households. The community that lives near the dike, made up largely of elderly, disabled and (often illegal) migrant households, are supportive and pool their resources together in order to help each other. In addition, due to the growing clam aquaculture industry she has been able to receive loans from rich owners (usually with interest payable). Although she feels that the rich owners look down on the dike community, they will still employ them to work on their fields, but she still relies heavily on foraged MSPG for food for subsistence. This space, however, has vastly reduced and she must travel through the clam aquaculture fields to get there, and although she can make extra income from collecting the litter thrown from the clam field watchtowers, she must be careful not to stray too close to the fields otherwise the owners will attack her. In addition, because people can make money from foraging MSPG now, they will commit more time and effort which means there are less animals to catch. Although she is aware of some livelihood opportunities available through various NGO projects, she is unable to get to the Women's Union meetings where opportunities are distributed, and she believes that she does not have the adequate level of skills and knowledge required to participate in the projects. Not only that, but these opportunities are usually shared among the families of union leaders
Factors leading to resilience $(R)$ and vulnerability $(V)$

R1. Access to natural resources

R2. Salaried employment

R3. Access to markets

R4. Access to knowledge

V1. Loss of natural capital

R5. Draws on financial capital

R6. Access to social networks

V2. Loss of productive capacity

R7. Accumulates land

R8. Draws on financial capital

R9. Rise in demand for aquaculture products

R10. Regulating ecosystem service

V3. Uncertainty due to suppression of ecosystem functions and processes

V1. Lack of subsistence

V2. Lack of financial capital

V3. Lack of state support

R1. Access to ecosystem provisions

V4. Debt accumulation

V5. Loss of labour

R2. Family support network

V6. Lack of access to land

R3. Salaried employment

R4. Applied human capital

R5. Extended social networks

R6. Gain in human capital

V7. Unstable income

R7. Provisional ecosystem service

V8. Climatic impact on crops

V9. Loss of access to ecosystem services

V10. Altering ecosystem causes increased livelihood uncertainty

R1. Access to ecosystem services

V1. Loss of access to ecosystem services

R2. Diversification of income

V2. Loss of human capital

V3. Loss of income

V4. Accumulation of debt

V5. Selling of assets

V6. Low quality land for arable crops

V7. Target of crime

R3. Social support networks

R4. Access to loans

V8. Discrimination

R5. Ecosystem service

V9. Loss of access to land

V10. Overexploitation of resources

V11. Lack of access to village meetings

V12. Lack of awareness

V13. Elite capture 
Table 6 continued

\begin{tabular}{|c|c|}
\hline Case study household & $\begin{array}{l}\text { Factors leading to resilience }(R) \text { and vulnerability } \\
(V)\end{array}$ \\
\hline $\begin{array}{l}\text { Case 4-Male, age 37, Dong Rui } \\
\text { In 1979, he moved to Dog Rui from Hai Phong City as part of the resettlement programme. Life was difficult } \\
\text { in the city with little work, and resettlement offered a house with land to cultivate and 6-month worth of rice } \\
\text { from the state to help with the transition. The abundance of natural resources meant that food was easy to } \\
\text { obtain and life was good. In 1986, encouraged by the local People's Committee, he took out a substantial } \\
\text { loan to invest in a wetland boundary pond to allow more effective capture of marine creatures. This was very } \\
\text { productive for the first } 2-3 \text { years, but then productivity sharply declined due to the impact the ponds had on } \\
\text { the natural flow of water and the environment. Many residents raised this as an issue at village meetings at } \\
\text { the time, but their concerns were not acted upon by the authorities. As the bank loan repayments were } \\
\text { mounting, he took out further loans in the hope that the pond would become productive again. This did not } \\
\text { happen and eventually he gave up on the pond. For a while he could still make a living foraging MSPG in the } \\
\text { vast wetland area, but when huge areas started to be sold to investors from other provinces this reduced the } \\
\text { commons area. Furthermore, pollution from the clam aquaculture fields destroyed the surrounding area, } \\
\text { which drove him to destitution. He was the victim of unscrupulous human traffickers to whom he paid } \\
\text { money, provided to him by his wife's family in Hai Phong, on the understanding that he would gain well- } \\
\text { paid employment in China. On arrival the hours were long, conditions were terrible and the pay was very } \\
\text { low, so he fled back to Dong Rui, putting his life in danger and swimming across dangerous waters in order } \\
\text { to cross the border from China to Vietnam. Additionally, his rice, peanut and sweet potato crops have been } \\
\text { impacted by rapidly changing and unpredictable weather in recent years, with the winters becoming colder } \\
\text { and the summer hotter. The irrigation system is inadequate, the quality of local soil is sandy, salty and of } \\
\text { poor quality, and this restricts the options for changing crops, planting times and varieties. If people do not } \\
\text { get enough rice, they go hungry, but he is lucky that he is still strong and can sell labour to a nearby paper } \\
\text { factory and use his earnings to buy rice }\end{array}$ & $\begin{array}{l}\text { R1. Access to ecosystem services } \\
\text { R2. Access to loans } \\
\text { V1. Loss of ecosystem function and process } \\
\text { V2. Accumulating debt } \\
\text { V3. Loss of income } \\
\text { R3. Access to ecosystem service } \\
\text { V4. Loss of access to ecosystem service } \\
\text { V5. Onset of poverty } \\
\text { V6. Vulnerable target of human trafficking } \\
\text { syndicates } \\
\text { V7. Negative climatic impact on crops } \\
\text { V8. Poor infrastructure } \\
\text { V9. Poor quality } \\
\text { V10. Lack of diverse cropping options } \\
\text { R4. Human capital }\end{array}$ \\
\hline Case 5-Female, age 33, Dong Rui & V1. Loss previous support mechanisms \\
\hline $\begin{array}{l}\text { She is from the Dao ethnic minority, originally from the mountainous region of the province, and has lived in } \\
\text { Dong Rui for } 12 \text { years since they were resettled here by the government. The Dao community were promised } \\
\text { a better life in Dong Rui, but since arriving she has wanted to return to her home. The district authorities, } \\
\text { however, have already converted the land they left for another purpose so she cannot return. She arrived with } \\
\text { a small number of other Dao families, but as they did not speak, Vietnamese were not familiar with the } \\
\text { environment, and because they have different customs, beliefs and traditions to the ethnic "kinh" } \\
\text { Vietnamese, they struggled to integrate into the local community. They soon became isolated and were } \\
\text { pushed into the area with lower-quality land where it is difficult to grow crops. Almost all of her income } \\
\text { comes from foraging MSPG, and this has been so since she and her family arrived, but she is given a lower } \\
\text { price than the ethnic "kinh" wholesaler. Some Dao go to forage MSPG in groups and have developed } \\
\text { effective techniques for catching animals, but she is not involved in any of these groups. These groups have } \\
\text { become rich, but she remains poor. She has to pay community fees, but she is unsure exactly what this is for } \\
\text { as she is very poor but receives no state support }\end{array}$ & $\begin{array}{l}\text { V2. Communication difficulties } \\
\text { V3. Alienation from wider community } \\
\text { V4. Lack of income diversity } \\
\text { V5. Discrimination } \\
\text { V6. Lack of skills } \\
\text { V7. Lack of state support }\end{array}$ \\
\hline
\end{tabular}

diversity and moderately secure land-use rights. These households have been able to improve their livelihood trajectory and gain employment mainly on aquaculture farms (and in construction or manufacturing) through a combination of human capital, social networks and forging reputations as good workers. However, as aquaculture has increased the number of livelihood strategies available to the community, these households have reduced the number of livelihood activities that they engage in, becoming more specialised in aquaculture employment. Some households have been able to either gain access to bank loans or pool resources with family or friends to obtain formal tenure rights and develop aquaculture farms. The local economy provides a sufficient living for these households, and they can overcome livelihood disturbance by seeking alternative employment opportunities beyond the locality if they have an adequate level of human capital. Many of these households still use MSPG to supplement their income, for household use, or in times of livelihood shock and stress.
The third group, (marginalised) were typically from poor backgrounds prior to political and economic reforms and are currently marginalised due to a lack of power, influence and severely limited access to livelihood resources (e.g. labour, skills, networks, capital). These households are struggling to survive and are characterised by low incomes, young, female heads, high livelihood diversity and insecure land-use rights. These households lacked social influence or access to employment opportunities and relied heavily on MSPG for income and subsistence. Usually, they were unable to take advantage of opportunities to access land and resources following political and economic reform due to a lack of social networks and human capital. Increased pressure on mangrove systems from aquaculture disproportionately affects households in this group, who are least able to defend livelihoods or take advantage of market opportunities. Many households shifted from the accumulator group to this group following sickness or death of household 
members which greatly increased livelihood vulnerability. Other households shifted from the accumulator group to this group subsequent to mounting debts due to failed aquaculture ventures as a result of lack of adequate skills or knowledge. Recently, settled migrants lacking social networks and local knowledge also form a large proportion of this group. To cope with shocks, these households increase livelihood diversity, rely on support from family and close friends and increase their use of MSPG for subsistence and income. However, the impact of aquaculture means they face reduced mangrove system common areas from which to collect MSPG. Feedbacks from rapid economic development (i.e. aquaculture) have also exacerbated negative impacts such as biodiversity loss and water cycle disruption, which has led to reductions in the quantity and quality of MSPG collected. Subsequently, marginalised households often rely on loans, some have pre-existing debt from failed aquaculture ventures, and households often resort to asset selling and move to cheaper, unproductive land. Here, households are susceptible to alienation from the community and often become targets of crime. Other households may have fallen out with local authorities who then use their power and influence to make life difficult for them, and if these households do not have sufficiently strong social networks or human capital to fall back on, they can quickly fall into this group. Households in this group are likely to experience trajectory lock-ins due to lack of access to resources, networks and a greatly reduced and degraded mangrove system commons.

Results highlight the factors that have shaped the resilience and vulnerability of household livelihoods. Factors that increase resilience of consolidator and accumulator livelihood trajectories were: access to aquaculture market opportunities (e.g. employment, knowledge, networks, finance); access to more secure tenure rights; high levels of human capital; and access to support networks and MSPG to buffer disturbance. Factors found to increase vulnerability within the marginalised livelihood trajectory were: loss of access to MSPG reducing buffer to disturbance; low incomes and susceptibility to poverty (e.g. sickness, debt, asset selling); negative environmental impacts from aquaculture (e.g. alteration in ecological processes, exposure to climatic shocks and stresses); discrimination; and elite capture reducing response options.

\section{Discussion}

Integrating ecosystem service and livelihood trajectory approaches provided the opportunity to analyse current uses of MSPG in livelihoods between and within communities, and the aspects influencing past livelihood decisions and uses of mangrove system goods and services in response to disturbance. Understanding how this has shaped livelihood trajectories is crucial for understanding the dynamics and interdependencies of mangrove systems and livelihood strategies (Trabucchi et al. 2012; Sallu et al. 2010).

\section{Key aspects of mangrove system change}

Aquaculture was found to be the primary driver of mangrove system change, consistent with findings across Southeast Asia (Kirui et al. 2013). Aquaculture encapsulates the key aspects of mangrove system change identified by communities, i.e. changes in mangrove system tenure arrangements, market liberalisation and elite capture. Increased intensification and specialisation of mangrove system land subsequent to the rapid increase in aquaculture is severely undermining ecosystem functions and processes, in line with findings from Power (2010). Consistent with Gunderson and Holling (2002), feedbacks from rapidly growing aquaculture have exacerbated negative environmental impacts (e.g. biodiversity loss, water cycle disruption). Hence, mangrove system declines, and degradation from conversion to aquaculture has: (1) reduced livelihood resilience through vegetation and biodiversity loss, lowering livelihood options to buffer the impacts of disturbance (cf. Sonwa et al. 2012) and (2) increased the livelihood vulnerability of marginalised households through greater exposure to disturbance and increased sensitivity due to increasingly negative effects from disturbance (cf. Walker et al. 2006).

\section{Livelihood strategies and activities}

High levels of aquaculture are associated with: greater livelihood vulnerability due to the concentration of wealth among aquaculture farmers and lower livelihood resilience due to lower levels of household livelihood diversity. The distribution of MSPG is becoming increasingly unequal and determined by market forces that serve the interests of elites, while marginalised households face reduced access due to the degradation and loss of mangrove system commons. In line with Adger et al. (2006), income inequality has created vulnerable groups through the concentration of resources among a small number of individuals, thus reducing the livelihood options of marginalised households. Income from MSPG can reduce income inequality. Results show that communities with high levels of aquaculture activity are associated with lower average household livelihood diversity, although livelihood diversity is greater among marginalised groups in these communities. Pomeroy et al. (2006) argue that greater livelihood diversity increases resilience by reducing household dependency on any single income source and 
provides flexibility by spreading risk among a number of livelihood activities to buffer disturbance. Hence, MSPG can effectively increase livelihood resilience, offering diversification into a low-cost activity requiring little capital outlay.

\section{Household characteristics and mangrove system dependency and use}

In communities with high levels of aquaculture activity, marginalised groups are increasingly vulnerable due to high dependence on MSPG from degraded and declining mangrove system commons. Results indicate that MRDC are differentiated socio-economically with households exhibiting a variation of dependency on MSPG. Results support other findings from Vietnam (Van Hue 2006) and Ethiopia (Asfaw and Satterfield 2010) where entrenched customary norms and patriarchal cultures constrain women's access to land. Subsequently, female-headed households depend more on MSPG from mangrove system commons. In communities with high levels of aquaculture activity, households earning high incomes from aquaculture have less need to diversify, while low-income households diversify to reduce risk from external disturbances. Conversely, in communities with less aquaculture activity, households able to access a diverse range of livelihood activities, particularly off-farm activities, have less dependence on mangroves. Barrett et al. (2005) state that inter-household heterogeneity plays a fundamental role in determining livelihood diversification patterns, and the constraints and incentives facing various groups must factor prominently in analyses of livelihood diversification. MSPG collection was considered by marginalised households to be the most important response to cope with disturbance. Consistent with findings in Zambia (Kalaba et al. 2013), the sale of forest products was more important than support from kinship ties due to a lack of economic prosperity among kinship networks. It is crucial to consider the impacts that changes in mangrove systems have on household coping strategies and livelihoods (Trabucchi et al. 2012).

\section{Livelihood trajectories}

A household's current livelihood portfolio is largely shaped by factors affecting past livelihood actions, particularly access to ecosystem goods and services (Nyamwanza 2012). Pre-existing conditions (e.g. political power and resource access) shape current livelihoods by influencing access to resources (i.e. natural resources, finance, secure tenure rights, knowledge, technology, social networks, markets). Consolidator households were able to appropriate mangrove system goods and services by using their access to resources to establish successful aquaculture farms, with the subsequent degradation and loss of mangrove system commons depriving marginalised households of MSPG. Pellow (2000) argues that exploring such issues of power helps us to understand how and why people suffer from reduced access to natural resources and subsequent vulnerability. Aquaculture has increased the intensification and specialisation of mangrove system cultivation, severely undermining system functions and processes, and disproportionately affecting the livelihoods of those households most dependent on MSPG. This corresponds with findings from Gunawardena and Rowan (2005) in their study of the Rekawa Lagoon system of Sri Lanka, where the negative environmental impacts from aquaculture had disproportionately large impacts on traditional livelihoods. Changes in national-level structures combine with local-level responses to shape multiple livelihood trajectories, such that development gains at the national level ignore crucial environmental justice issues at the local level (Sikor 2001). However, while different, the livelihood trajectories of various groups are interconnected.

Harnessing the knowledge gained through dialogue with the households involved in this study, it was observed that perceptions of potential solutions to enhance livelihood trajectories differed significantly between consolidator and accumulator/marginalised groups. The consolidator group typically expressed their desire for less government interference in the form of tax on their profits and regulations that restrict their management decisions. This, they argued, would enable them to further develop and manage their aquaculture farms as they see fit, which, they believe, would benefit the wider community through increased employment opportunities. Another opinion from consolidators was that successful aquaculture farmers should invest in sustainable development by considering the environmental impact of aquaculture practices. Owners should focus on developing native varieties of aquaculture goods instead of importing alien species and modifying the environment to accommodate them. This was viewed as unsustainable due to the damage caused to the surrounding area. Conversely, respondents from accumulator and marginalised groups expressed the need for more accountable and participatory governance processes. This was due to the perceived unjust distribution of the benefits derived from mangrove system resources which limits their livelihood options. These groups believe that local authority figures are typically appointed by high-ranking Communist Party officials, rather than electing through local elections, which they perceived as a façade. These appointed authority figures typically have little concern for the local communities or environment that they are supposed to represent. Accumulator and marginalised groups suggest that communities should be better able to access higher 
levels of government in order to mitigate the power of local authorities and elite capture, which they viewed as one some of the most restricting factors in shaping household livelihood trajectories.

\section{Conclusion}

By analysing aspects of mangrove system change and the factors that shape household responses, our findings highlight the importance of considering how these interacting elements have shaped livelihoods in three MRDC in northern Vietnam. By using a framework that provides a time dimension to the analyses of household mangrove system use, we have shown how the context within which aquaculture develops, as well as the socio-economic characteristics of households, shapes the vulnerability and resilience of household livelihoods. While calls for efforts to increase mangrove system conservation and restoration in order to increase livelihood resilience are welcomed, it must be acknowledged that MRDC do not use and respond homogenously to mangrove system change.

Findings illustrate how transition processes have altered the governance of mangrove systems through the increasing influence of market mechanisms. For example, households with access to finance, skills, networks and markets have been able to take advantage of the opportunities presented by transition to develop successful aquaculture farms and increase their livelihood resilience. However, aquaculture negatively impacts marginalised households by restricting access and degrading mangrove system resources crucial for households with limited or no access to market opportunities. We have shown how the livelihoods of the marginalised are becoming increasingly vulnerable through: (1) income inequality and the concentration of wealth among a small number of households which diverts resources away from the most marginalised and (2) restricted options for livelihood diversity through limited access and degradation of mangrove systems. Therefore, the impact of aquaculture must be considered if policies to sustainably manage mangrove systems are to be successful. Identifying the characteristics of those households most dependent on MSPG and vulnerable to change is crucial in order to provide targeted livelihood support to those who need it most. Further research will be necessary to identify the specific kinds of support vulnerable groups require, in addition to their desire for greater voice in decision-making. Policies aimed at increasing access of marginalised households to mangrove system resources can reduce income inequalities while increasing livelihood diversification opportunities, thereby increasing resilience. Further research is necessary to understand the institutional structures and processes within which the limits and constraints for increasing access to mangrove system resources exist.

Findings presented here highlight important features of communities that should be considered within environmental governance more widely. For example, the increased influence of market mechanisms on mangrove system governance, income inequality and subsequent constraints on livelihood diversity create path dependencies that shape future options in response to mangrove system change, locking marginalised households into vulnerable livelihood trajectories. How mangrove system change affects livelihoods depends on household characteristics and local context and will manifest differently depending on the equitable and just distribution of resources necessary for the sustainable governance and use of mangrove systems.

Acknowledgments This work was funded through the Economic and Social Research Council Centre for Climate Change Economics and Policy (CCCEP). We are grateful to the communities of Giao Xuan, Da Loc and Dong Rui, Marinelife Conservation and Community Development (MCD), the Centre for Natural Resource and Environment Studies (CRES) and CARE Vietnam.

Open Access This article is distributed under the terms of the Creative Commons Attribution 4.0 International License (http:// creativecommons.org/licenses/by/4.0/), which permits unrestricted use, distribution, and reproduction in any medium, provided you give appropriate credit to the original author(s) and the source, provide a link to the Creative Commons license, and indicate if changes were made.

\section{References}

Adger WN (2000) Institutional adaptation to environmental risk under the transition in Vietnam. Ann Assoc Am Geogr 90(4):738-758. doi:10.1111/0004-5608.00220

Adger WN, Paavola J, Huq S, Mace MJ (2006) Fairness in adaptation to climate change. MIT Press, Cambridge

Armitage D, Béné AT, Charles D, Johnson D, Allison EH (2012) The interplay of well-being and resilience in applying a social-ecological perspective. Ecol Soc 17(4):15. doi:10.5751/ES-04940-170415

Asfaw T, Satterfield T (2010) Gender relations in local-level dispute settlement in Ethiopia's Zeghie Peninsula. Hum Ecol Rev 17 (2):160-174

Bagchi DK, Blaikie P, Cameron J, Chattopadhyay M, Gyawali N, Seddon D (1998) Conceptual and methodological challenges in the study of livelihood trajectories: case-studies in Eastern India and Western Nepal. J Int De Plan Rev 10:453-468. doi:10.1002/ (SICI)1099-1328(199806)10:4<453:AID-JID538>3.0.CO;2-Q

Barrett CB, Bezuneh M, Clay D, Reardon T (2005) Heterogeneous constraints, incentives and income diversification strategies in rural Africa. Q J Int Agric 44(1):37-60

Brouwer R, Sonia A, Luke B, Enamul H (2007) Socioeconomic vulnerability and adaptation to environmental risk: a case study of climate change and flooding in Bangladesh. Risk Anal 27 (2):313-326. doi:10.1111/j.1539-6924.2007.00884.x

Carpenter SR, Mooney HA, Agard J et al (2009) Science for managing ecosystem services: beyond the millennium ecosystem 
assessment. Proc Natl Acad Sci USA 106(5):1305-1312. doi:10. 1073/pnas.0808772106

Chambers R, Conway G (1992) Sustainable rural livelihoods: practical concepts for the 21 st century. Institute for development studies, Discussion paper 296

Cox M, Arnold G, Tomas SV (2010) A review of design principles for community-based natural resource management. Ecol Soc 15 (4):38

Duit A, Galaz V, Eckerberg K, Ebbesson J (2010) Governance, complexity and resilience. Glob Environ Change 20:363-368. doi:10.1016/j.gloenvcha.2010.04.006

Ellis F (2000) The determinants of rural livelihood diversification in developing countries. J Agric Econ 51:289-302

Friess DA, Phelps J, Leong RC et al (2012) Mandai mangrove, Singapore: lessons for the conservation of Southeast Asia's mangroves. Raffles Bull Zool (25):55-65

Glaser M (2003) Interrelations between mangrove ecosystem, local economy and social sustainability in Caete Estuary, North Brazil. Wetl Ecol Manag 11(4):265-272. doi:10.1023/A: 1025015600125

Gopal B (2013) Future of wetlands in tropical and subtropical Asia, especially in the face of climate change. Aquat Sci 75(1):39-61. doi:10.1007/s00027-011-0247-y

Gunawardena M, Rowan JS (2005) Economic valuation of a mangrove ecosystem threatened by shrimp aquaculture in Sri Lanka. Environ Manag 36(4):535-550. doi:10.1007/s00267-0030286-9

Gunderson L, Holling CS (2002) Panarchy: understanding transformations in human and natural systems. Island Press, Washington DC

Heckathorn D (1997) Respondent-driven sampling: a new approach to the study of hidden populations. Soc Probl 44(2):174-199. doi:10.1525/sp.1997.44.2.03x0221m

Kalaba FK, Quinn CH, Dougill AJ (2013) Contribution of forest provisioning ecosystem services to rural livelihoods in the Miombo woodlands of Zambia. Popul Environ 35(2):159-182. doi:10.1007/s11111-013-0189-5

Kaplowitz D (2001) Assessing mangrove products and services at the local level: the use of focus groups and individual interviews. Landsc Urban Plan 56(1-2):53-60. doi:10.1016/S0169-2046(01) 00170-0

Kirui KB, Kairo JG, Bosire J (2013) Mapping of mangrove forest land cover change along the Kenya coastline using Landsat imagery. Ocean Coast Manag 83:19-24. doi:10.1016/j.ocecoaman.2011. 12.004

Luttrell C (2006) Adapting to aquaculture in Vietnam: Securing livelihoods in a context of change in two coastal communities. In: Hoanh CT et al (eds) Environment and livelihoods in tropical coastal zones: managing agriculture-fishery-aquaculture conflicts. CAB International, Wallingford, UK, pp 17-29

Marschke MJ, Berkes F (2006) Exploring strategies that build livelihood resilience: a case from Cambodia. Ecol Soc 11(1):42

MEA (2005) Millennium ecosystem assessment: ecosystems and human well-being: general synthesis. Island Press and World Resources Institute, Washington DC

Norgaard RB (2010) Ecosystem services: from eye-opening metaphor to complexity blinder. Ecol Econ 69(6):1219-1227. doi:10.1016/ j.ecolecon.2009.11.009
Nyamwanza AM (2012) Livelihood resilience and adaptive capacity: a critical conceptual review. J Disaster Risk Stud 4(1):55. doi:10. 4102/jamba.v4i1.55

Pellow DN (2000) Environmental Inequality Formation-Toward a theory of environmental injustice. Am Behav Sci 43:581-601. doi:10.1177/0002764200043004004

Pomeroy RS, Ratner BD, Hall SJ, Pimoljinda J (2006) Coping with disaster: rehabilitating coastal livelihoods and communities. Mar Policy 30(6):786-793. doi:10.1016/j.marpol.2006.02.003

Power AG (2010) Ecosystem services and agriculture: tradeoffs and synergies. Philos Trans R Soc B 365:2959-2971. doi:10.1098/ rstb.2010.0143

Sallu SM, Twyman C, Stringer LC (2010) Resilient or vulnerable livelihoods? Assessing livelihood dynamics and trajectories in rural Botswana. Ecol Soc 15(4):3

Scoones I (1998) Sustainable rural livelihoods: a framework. IDS Working Paper 72

Sikor T (2001) Agrarian differentiation in post-socialist societies: evidence from three upland villages in north-western Vietnam. Dev Change 32(5):923-949. doi:10.1111/1467-7660.00232

Sonwa DJ, Somorin OA, Jum C, Bele MY, Nkem JN (2012) Vulnerability, forest-related sectors and climate change adaptation: the case of Cameroon. For Policy Econ 23:1-9. doi:10. 1016/j.forpol.2012.06.009

Spalding M, Kainuma M, Collins L (2010) World atlas of mangroves. Earthscan, London

To PX, Dressler WH, Mahanty S, Thu TP, Zingerli C (2012) The prospects for payment for ecosystem services (PES) in Vietnam: a look at three payment schemes. Hum Ecol 40(2):237-249. doi:10.1007/s10745-012-9480-9

Trabucchi M, Ntshotsho P, O'Farrell P, Comin FA (2012) Ecosystem service trends in basin-scale restoration initiatives: a review. J Environ Manag 111:18-23. doi:10.1016/j.jenvman.2012.06. 040

Tri NH, Adger NW, Kelly NP (1998) Natural resource management in mitigating climate impacts: the example of mangrove restoration in Vietnam. Glob Environ Change 8(1):49-61. doi:10.1016/S0959-3780(97)00023-X

Van Hue LT (2006) Gender, Doi Moi and Mangrove management in Northern Vietnam. Gend Technol Dev. doi:10.1177/0971852405 01000103

Van Hue LT, Scott S (2008) Coastal livelihood transitions: socioeconomic consequences of changing mangrove forest management and land allocation in a commune of Central Vietnam. Geogr Res 46(1):62-73. doi:10.1111/j.1745-5871.2007.00492.x

Vilardy SP, González JA, Martín-López B, Montes C (2011) Relationships between hydrological regime and ecosystem services supply in a Caribbean coastal wetland: a socialecological approach. Hydrol Sci J 56:1423-1435. doi:10.1080/ 02626667.2011.631497

Walker B, Holling CS, Carpenter SR, Kinzig A (2004) Resilience, adaptability and transformability in social-ecological systems. Ecol Soc 9(2):5

Walker BH, Anderies JM, Kinzig AP, Ryan P (2006) Exploring resilience in social-ecological systems through comparative studies and theory development: Introduction to the special issue. Ecol Soc 11(1):12 